\title{
In vitro cytotoxicity evaluation of thiourea derivatives bearing Salix sp. constituent against HK-1 cell lines
}

Norsyafikah Asyilla Nordin, Vannessa Lawai, Zainab Ngaini, Ainaa Nadiah Abd Halim, Siaw San Hwang, Reagan Entigu Linton, Boon Kiat Lee \& Paul Matthew Neilsen

To cite this article: Norsyafikah Asyilla Nordin, Vannessa Lawai, Zainab Ngaini, Ainaa Nadiah Abd Halim, Siaw San Hwang, Reagan Entigu Linton, Boon Kiat Lee \& Paul Matthew Neilsen (2020) In vitro cytotoxicity evaluation of thiourea derivatives bearing Salix $s p$. constituent against HK-1 cell lines, Natural Product Research, 34:11, 1505-1514, DOI: 10.1080/14786419.2018.1517120

To link to this article: https://doi.org/10.1080/14786419.2018.1517120

View supplementary material $₫$

Published online: 03 Dec 2018.

Submit your article to this journal ¿

Џ Article views: 96

Q View related articles $₫$

View Crossmark data $\nearrow$ 


\title{
In vitro cytotoxicity evaluation of thiourea derivatives bearing Salix sp. constituent against HK-1 cell lines
}

\author{
Norsyafikah Asyilla Nordin ${ }^{\mathrm{a}, \mathrm{b}}$, Vannessa Lawai ${ }^{\mathrm{b}}$, Zainab Ngaini ${ }^{\mathrm{b}}$, Ainaa Nadiah \\ Abd Halim ${ }^{b}$, Siaw San Hwang ${ }^{c}$, Reagan Entigu Linton ${ }^{c}$, Boon Kiat Lee ${ }^{c}$ and \\ Paul Matthew Neilsen ${ }^{d}$ \\ ${ }^{\mathrm{a}}$ Faculty of Pharmacy, Universiti Sultan Zainal Abidin, Besut Campus, Terengganu, Malaysia; ${ }^{\mathrm{b}}$ Faculty of \\ Resource Science and Technology, Universiti Malaysia Sarawak, Sarawak, Malaysia; ' ${ }^{\mathrm{C}}$ Faculty of Engineering, \\ Computing and Science, Swinburne University of Technology Sarawak Campus, Sarawak, Malaysia; \\ ${ }^{\mathrm{d} S}$ School of Health Medical and Applied Sciences, Central Queensland University, Norman Gardens, Australia
}

\begin{abstract}
In searching for drugs from natural product scaffolds has gained interest among researchers. In this study, a series of twelve halogenated thiourea (ATX 1-12) via chemical modification of aspirin (a natural product derivative) and evaluated for cytotoxic activity against nasopharyngeal carcinoma (NPC) cell lines, HK-1 via MTS-based colorimetric assay. The cytotoxicity studies demonstrated that halogens at meta position of ATX showed promising activity against HK-1 cells (IC $\mathrm{C}_{50}$ value $\leq 15 \mu \mathrm{M})$ in comparison to cisplatin, a positive cytotoxic drug $\left({ }^{\prime} C_{50}\right.$ value $=8.9 \pm 1.9 \mu \mathrm{M})$. ATX 11, bearing iodine at meta position, showed robust cytotoxicity against HK-1 cells with an $\mathrm{IC}_{50}$ value of $4.7 \pm 0.7 \mu \mathrm{M}$. Molecular docking interactions between ATX 11 and cyclooxygenase-2 demonstrated a robust binding affinity value of $-8.1 \mathrm{kcal} / \mathrm{mol}$ as compared to aspirin's binding affinity value of $-6.4 \mathrm{kcal} / \mathrm{mol}$. The findings represent a promising lead molecule from natural product with excellent cytotoxic activity against NPC cell lines.
\end{abstract}

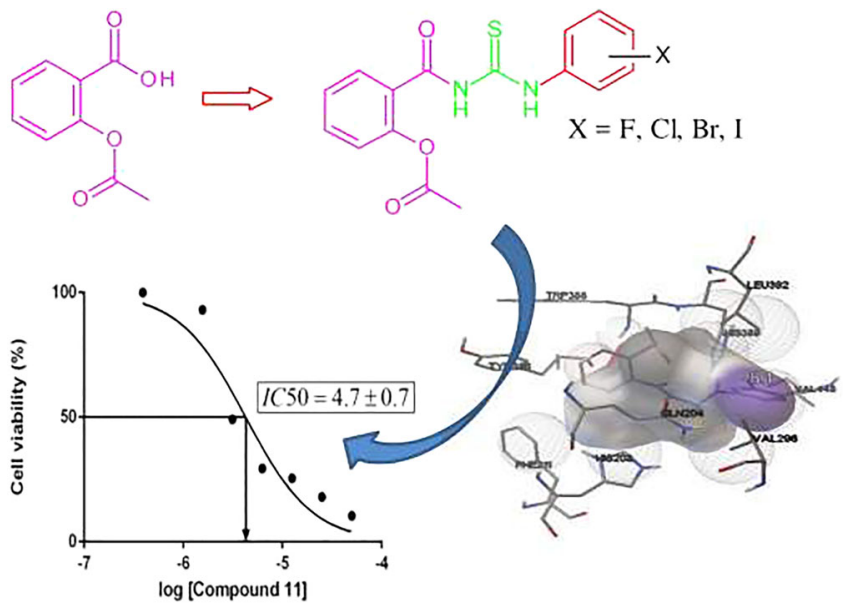

\section{ARTICLE HISTORY}

Received 7 May 2018

Accepted 24 August 2018

\section{KEYWORDS}

Aspirin; thiourea;

cytotoxicity; molecular

docking; cyclooxygenase-2

CONTACT Zainab Ngaini nzainab@unimas.my

(4) Supplemental data for this article can be accessed https://doi.org/10.1080/14786419.2018.1517120. 